
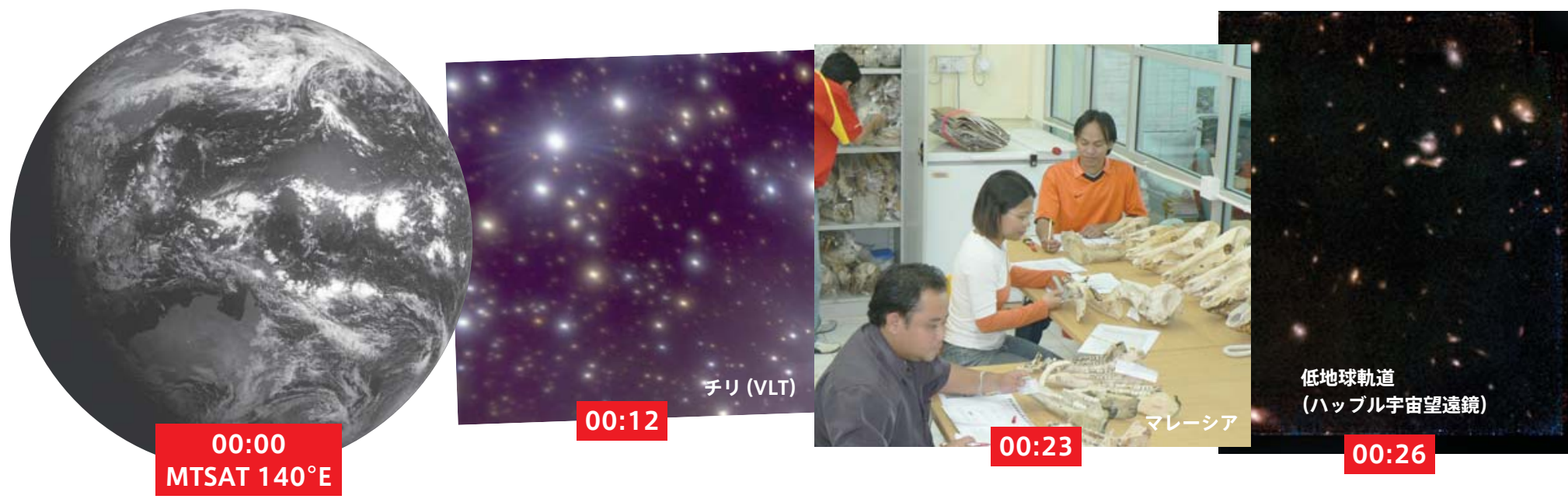

\title{
Science on the solstice
}

\section{科学する惑星——夏至の日}

Nature Vol.441(1040-1045)/29 June 2006

科学者たちは日々、地球上のあらゆる場所で、あるいはその外側で、私たちが住むこの世界を理解しようと努力を続け ている。ここに紹介するのは、そんなある 1 日の群像だ。2006 年 6 月 21 日、北半球でいうところの夏至の日一。

チリ・セロパラナル

世界時 00:12

欧州南天天文台にある望遠鏡 群「VLT」の 4 番目の望遠鏡 「イェプン」の制御卓について いるのは Morten Andersen。 銀河系内に見つかった、若い 星がひしめく巨大な超星団 「ウェスタールンド 1」の最小 の星々を一斉調査している。

現地時間 20:12（6月20日） 南緯 24 度 38 分、西経 70 度 24 分

マレーシア・ビントゥル 世界時 00:23

ボルネオ島にあるプトラマ レーシア大学ビントゥル校で 「人工林計画」の実行役員を務 めている Diana James Junau が、イノシの頭がい骨から 取り出した大臼歯を測定して いた。これらの頭がい骨は、 ヒゲイノシシ (Sus barbatus)
の集団生物学研究に関する 5 か年計画の一環として収集さ れたもので、森林のあちこち が開墾された場合にイノシシ の従来の食料源が持続可能で あるか、今後調査される予定。 現地時間 08:23 北緯 3 度 10 分、 東経 113 度 02 分

低地球軌道

世界時 00:26

ハッブル宇宙望遠鏡が 1344 秒間の近赤外線露光を開始。 宇宙望遠鏡科学研究所 (米国 メリーランド州) の Anton Koekemoer は、このデー 夕を、これから終日かけて撮 影される同領域のデータと組 み合わせていく予定。これは 「ハッブル超深宇宙」画像撮影 計画の 1 つで、原始宇宙で最 初の光源だった遠方銀河の探 索がプロジェクトのねらいだ。
ベトナム・ハノイ

世界時 01:30

博士課程の大学院生 Nguyen VanHanh が、22 時間にわた り体外で成熟させた数個の卵子 を Bui Xuan Nguyen に見せて いた。Nguyenは、ラオスと ベトナムの国境だけに住む、世 界で最も希少な哺乳類の 1 つ のサオラ (ベトナムレイヨウ、 Pseudoryx nghetinhensis) とい うウシのクローン作製を計画し ており、そのためにこの卵子が 必要なのだ。湿地にすむこの水 牛の卵母細胞の一部は状態が よく、明瞭な極体がみられた。 Nguyenがこれらの卵子から 核を取り除き始めるかたわら で、同僚たちがいくつかのサオ ラ細胞を準備。両者の融合は正 午ごろになる予定だ。

現地時間 08:30 北緯 21 度 01 分、 東経 105 度 30 分
インド・バンガロール

世界時 02:55

この体重 3140 グラムの女の 赤ちゃんは、マニパル病院で現 地時間午前 8 時前に生まれた。 誇らしげな母と父、Rhadhika Sinha と Rajesh Sinha の 最 初の赤ちゃんで、この写真が 撮影されたとき、2人は彼女 の名前を思案しているところ だった。この子と同じ 2006 年 6 月 21 日に世界中で生ま れた新しい命の数は推定 35 万 8522。これは、この日に死ん だ人（約 15 万 5000）の倍以 上だ。そして、この日世界の

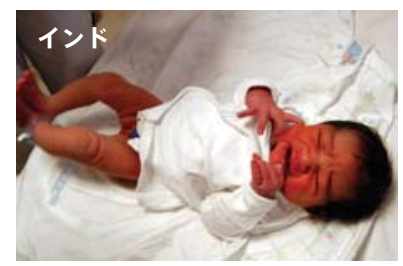



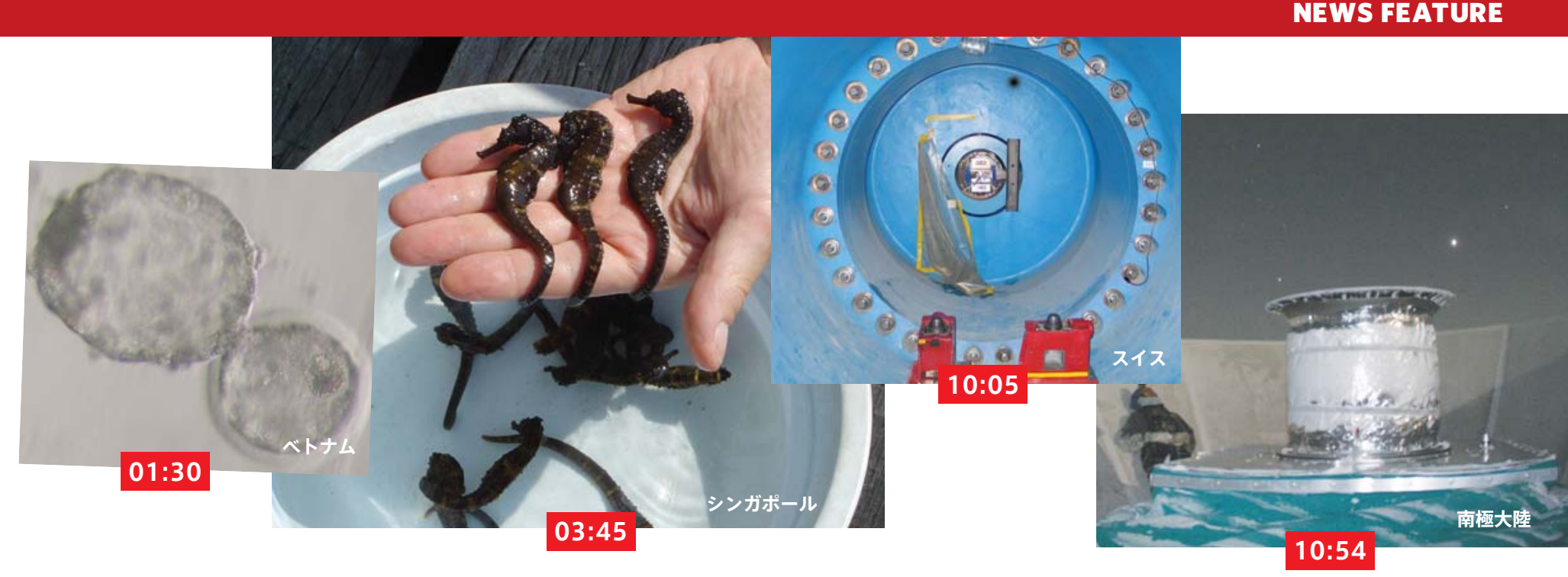

人口（推定）は 65 億 2364 万 2761 人となった。インドで生 まれた赤ちゃんは、これから 63.3 年生きる見込みで、これ は世界の平均寿命である 67 年 よりも少し短い。

現地時間 07:55 北緯 12 度 58 分、 東経 77 度 34 分

\section{シンガポール・ジョホール海峡}

\section{世界時 03:45}

シンガポール国立大学の Juan Walford と B. Sivaloganathan が、生後約 6 か月のタツノオト シゴの健康状態を調べている。 2 人はこのタツノオトシゴを、 シンガポール東岸沖の海上に浮 かんだ養魚場で育てている。研 究のねらいは、タッノオトシゴ を海洋環境の生きた指標にする こと。この日の朝、彼らはたく さんの「妊娠」したオスを見つ けた。若いオスたちは育児のう 中に胚をもっており、うまく生 殖年齢に達したことを示してい た。この分なら、この海域に稚 魚を放流することも可能だろう。 現地時間 11:45 北緯 1 度 24 分、 東経 103 度 58 分

アメリカ・ニュージャージー州

フローハムパーク

\section{世界時 03:47}

多国籍医療機器メ一カーの販売 部長 Dan Silver は、中国の新聞 記事を自ら翻訳し、「ProMEDmail」宛てに電子メールで送信
した。このインターネットサイト (http://www.promedmail. org）は感染症の突発情報を知 らせるもので、世界中の医師、 研究者、医療従事者などから寄 せられる情報に支えられている。 今回 Silver が送った記事では、 中国の陝西省で 6 月 12 日以降、 60 人の学生と教師が診断のつ かない熱病にかかったことを伝 えていた。

現地時間 23:47 (6月 20日) 北緯 40 度 47 分、西経 74 度 28 分

\section{日本・東京}

\section{世界時 04:00}

東京大学の古澤明の量子計算研 究室には、数百個の小さな鏡や ビームスプリッター、レンズなど が一見したところ乱雑に並んで いる。しかし、実際にはこれらの 装置は極めて注意深く準備され ているのだという。学生の 1 人が、 光子間の量子相関に関する世界 記録を破ろうと試みていた。

現地時間 13:00 北緯 35 度 43 分、 東経139度46 分

\section{低地球軌道 \\ 世界時 06:46}

国際宇宙ステーションに搭乗 している Jeffrey Williams が、 オーストラリア奥地にある 5 億 1500 万年以上前にできたとさ れる直径 $19 \mathrm{Km}$ の隕石孔を撮 影。この写真はWilliamsが今 日撮影予定の 3 枚のうちの 1 枚
目で、国際宇宙ステーションは、 さまざまな科学プロジェクトに 向けた一連の地球観測の一環と して、この撮影を行っている。

\section{日本・茨城県}

\section{世界時 07:24}

高エネルギー加速器研究機構 (KEK) のBファクトリーでは、 どんよりした天気にもかかわら ず鳥たちがさえずっている。加 速器中を走る電子と陽電子の ビーム強度は、世界のほかのど の加速器よりも高い。Bファクト リーで行われている Belle 実験 では、これまでに 5 億対の B 中 間子を記録した。Jasna Dragic は、KEKにいるほかの多くの研 究者と同じく大量のデータを分 析。モスクワで開かれる高エネ ルギー物理学国際会議で発表予 定の最新の実験結果に関する講 演に向けた準備をしているとこ ろだ。一方、彼女の同僚 Ruslan Chistov は、Physical Review Letters 誌へ 2 つの新粒子発見を 発表することに関し、Belle 実験 代表者の最終的許可が下りるの をイライラしながら待っている。 現地時間 16:24 北緯 36 度 09 分、 東経 140 度 04 分

\section{中国・昆明}

\section{世界時 08:35}

昆明霊長類研究センター。 Weizhiji は、アカゲザルの胚 のいくつかと体外受精によっ
て得られたクローン胚盤胞を、 共焦点顕微鏡で見るための準 備している。彼が関心をもっ ているのは、胚そのものを形 成することになる細胞と、胎 盤および羊膜を形成する細胞 でみられるそれぞれの遺伝子 活性の指標を比較することだ。 現地時間 16:35 北緯 25 度 04 分、 東経 102 度 42 分

\section{スリランカ・ペラデニヤ \\ 世界時 08:40}

ペラデニヤ大学の地質学者 Kapila Dahanayake は、2004 年 12 月の大津波に関する海水 や堆積物の試料を分析してい る。浸水した家から見つかった 空のアラック (蒸留酒の 1 種) の瓶に残っていた試料は、深海 に典型的な小型プランクトンを 含み、粒の大きさも特別な分布 をしている。近くの井戸の深さ $1.5 \mathrm{~m}$ 付近から採取した堆積物 も、この瓶の堆積物とよく似て いることから、津波によって運 ばれてきたものだと推定される。 現地時間 14:10 北緯 7 度 15 分、 東経 80 度 34 分

\section{南アフリカ・ベルビル}

\section{世界時 08:45}

南アフリカの国立バイオイン フォマティクス研究所では、 Winston Hide が抗レトロウイ ルス薬「ネビパリン」を使った 治療で起きた HIV の突然変異 
